\title{
Adipose Tissue Development and Expansion from the Womb to Adolescence: An Overview
}

\author{
Camila E. Orsso ${ }^{1}\left(\mathbb{D}\right.$, Eloisa Colin-Ramirez $\left.{ }^{2}{ }^{(}\right)$, Catherine J. Field $\left.{ }^{1}{ }^{(}\right)$, Karen L. Madsen $\left.{ }^{3}{ }^{(}\right)$, \\ Carla M. Prado ${ }^{1}$ and Andrea M. Haqq ${ }^{4, *}$ \\ 1 Department of Agricultural, Food and Nutritional Science, University of Alberta, Edmonton, \\ AB T6G 2E1, Canada; orsso@ualberta.ca (C.E.O.); cjfield@ualberta.ca (C.J.F.); \\ carla.prado@ualberta.ca (C.M.P.) \\ 2 Department of Pediatrics, University of Alberta, Edmonton, AB T6G 2E1, Canada; eloisa@ualberta.ca \\ 3 Department of Medicine, University of Alberta, Edmonton, AB T6G 2C2, Canada; karen.madsen@ualberta.ca \\ 4 Department of Pediatrics and Department of Agricultural, Food and Nutritional Science, \\ University of Alberta, Edmonton, AB T6G 2R7, Canada \\ * Correspondence: haqq@ualberta.ca; Tel.: +1-780-492-0015
}

Received: 12 August 2020; Accepted: 2 September 2020; Published: 8 September 2020

\begin{abstract}
Prevalence rates of pediatric obesity continue to rise worldwide. Adipose tissue (AT) development and expansion initiate in the fetus and extend throughout the lifespan. This paper presents an overview of the AT developmental trajectories from the intrauterine period to adolescence; factors determining adiposity expansion are also discussed. The greatest fetal increases in AT were observed in the third pregnancy trimester, with growing evidence suggesting that maternal health and nutrition, toxin exposure, and genetic defects impact AT development. From birth up to six months, healthy term newborns experience steep increases in AT; but a subsequent reduction in AT is observed during infancy. Important determinants of AT in infancy identified in this review included feeding practices and factors shaping the gut microbiome. Low AT accrual rates are maintained up to puberty onset, at which time, the pattern of adiposity expansion becomes sex dependent. As girls experience rapid increases and boys experience decreases in AT, sexual dimorphism in hormone secretion can be considered the main contributor for changes. Eating patterns/behaviors and interactions between dietary components, gut microbiome, and immune cells also influence AT expansion. Despite the plasticity of this tissue, substantial evidence supports that adiposity at birth and infancy highly influences its levels across subsequent life stages. Thus, a unique window of opportunity for the prevention and/or slowing down of the predisposition toward obesity, exists from pregnancy through childhood.
\end{abstract}

Keywords: adipose tissue; obesity; children; adolescence; development

\section{Introduction}

Prevalence rates of childhood obesity continue to rise worldwide. Analysis of data pooled from studies conducted between 1975 and 2016 revealed a $4.9 \%$ and $6.9 \%$ global increase in the prevalence of obesity among girls and boys aged 5-19 years, respectively [1]. Although the etiology of obesity is multifactorial, it can be simply defined as excess of body fat (or adiposity) [2]. Adipose tissue (AT) is one of the largest organs in the body and provides protection and support for other organs and acts as an endocrine tissue [3]. Recent research has shown the existence of varied AT subtypes, but only the brown and white AT have been extensively characterized in humans [3,4]. Although both AT types are important for energy homeostasis, they differ considerably given their characteristic distribution, lipid composition, and cytokine profiles (Table 1) [3,4]. Notably, the thermogenic role of 
brown AT contributes to insulin sensitivity and increased energy expenditure [5]. On the other hand, excess of white AT has been associated with metabolic dysfunction, reduced cardiorespiratory fitness, and psychological disorders during childhood [6-8]. White AT is generally classified as subcutaneous AT (SAT) or visceral AT (VAT); the latter is found in distinct depots (e.g., omental, epicardial, pericardial) and composed of heterogeneous cell types depending on the depot, conferring them specific metabolic signatures and capacity for development and expansion [9-11].

Adipose tissue development is a dynamic process. The first adipose cells, also called adipocytes, appear during the intrauterine period and continue to develop and expand throughout life [12]. Although AT accretion in each stage of development follows a general pattern that is specific to that stage, studies have shown that adiposity in prenatal life and infancy tracks into childhood and then into adulthood [13-17]. Several components have been shown to contribute to healthy (or unhealthy) AT growth, including genetic factors as well as prenatal and postnatal exposure to dietary, lifestyle, and environmental factors. Thus, there has been an extensive effort to develop effective preventive and treatment strategies targeting these determinants of AT expansion. In this narrative review, we describe the trajectories of AT development from the intrauterine period to late adolescence and examine the role of prenatal and postnatal factors that have been identified to contribute to its development and expansion. Articles discussed here were identified through a literature search in PubMed from its conception until August 2020. The search strategy consisted of a combination of keywords related to the following concepts: AT development and expansion, life stages, fetal programming, breastfeeding, environmental exposures, genetics, dietary intake, gut microbiome, and physical activity/exercise. Here, we focus on white AT (at the tissue level), as it is the largest component of total fat mass (FM; at the molecular level) and it has been extensively characterized in the pediatric population; specifically, about $80 \%$ of AT is FM [18].

Table 1. Key differences in morphology, distribution, and primary function between white and brown adipose tissues.

\begin{tabular}{|c|c|c|}
\hline & White Adipose Tissue $[3,19]$ & Brown Adipose Tissue [20] \\
\hline Morphology & $\begin{array}{l}\text { - Large unilocular lipid droplets: } 95 \% \text { of } \\
\text { cell volume is composed } \\
\text { of triglycerides } \\
\text { - Adipocytes with sparse } \\
\text { mitochondrial population } \\
\text { - UCP1 is not expressed }\end{array}$ & $\begin{array}{l}\text { - Small lipid droplets (multilocular) } \\
\text { Dense network of mitochondria and } \\
\text { vasculature in adipocytes } \\
\text { - High basal levels of the mitochondrial } \\
\text { UCP1 }\end{array}$ \\
\hline Distribution & $\begin{array}{l}\text { Found in subcutaneous and visceral } \\
\text { adipose tissues and ectopic depots } \\
\text { Distribution varies across age, sex, } \\
\text { nutritional status, and } \\
\text { metabolic health }\end{array}$ & $\begin{array}{l}\text { - Infants: interscapular and } \\
\text { perirenal regions } \\
\text { Adults: cervical, supraclavicular, } \\
\text { axillary, and suprarenal regions } \\
\text { - } \quad \text { Infants have greater amounts } \\
\text { than adults } \\
\text { - } \quad \text { Individuals with obesity have lower } \\
\text { quantity than those of normal weight }\end{array}$ \\
\hline Primary function & $\begin{array}{l}\text { Energy homeostasis: store lipids and } \\
\text { release energy in form of free fatty } \\
\text { acids and glycerol } \\
\text { - Endocrine: secretion of hormones, } \\
\text { pro-inflammatory cytokines } \\
\text { Mechanical: protect organs against } \\
\text { external mechanical stress, prevent } \\
\text { heat loss (insulator) }\end{array}$ & $\begin{array}{l}\text { - Cold-induced thermogenesis: produce } \\
\text { heat via the action of UCP1 } \\
\text { Energy expenditure }\end{array}$ \\
\hline
\end{tabular}

Abbreviation: UCP1: uncoupling protein 1. 


\section{Adipose Tissue Development}

The development and expansion of AT, with consequent increases in total body fat, are dynamic processes that begin in the second trimester of gestation and extend throughout life (Figure 1) [12]. These processes involve either enlargement of adipocyte cells by augmented lipid storage (i.e., hypertrophy) or increases in the number of adipocytes (i.e., hyperplasia) within a lobule through differentiated progenitor or mesenchymal cells [21]. Sun et al. further classify the AT expansion into healthy and unhealthy processes [22]. The first classification is related to the formation of small new adipocytes that are adequately vascularized and minimal inflammation is present [22].

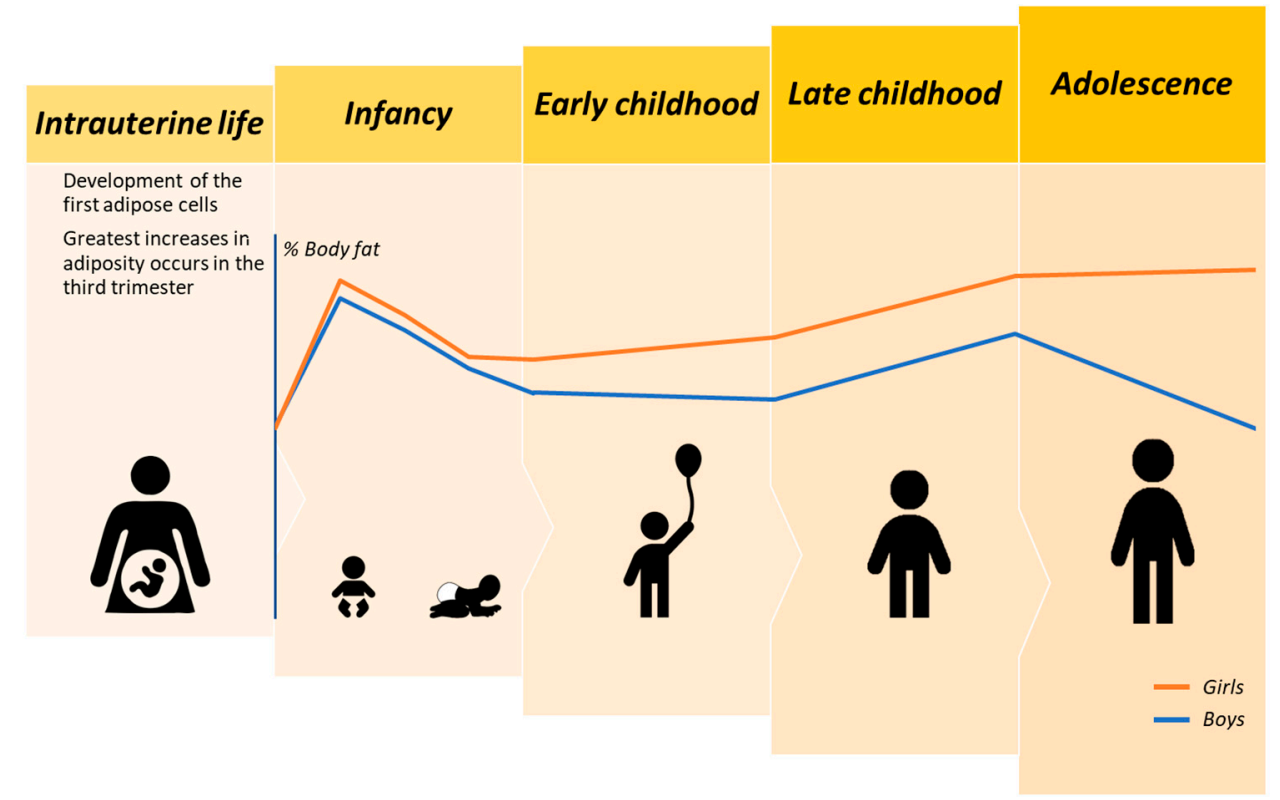

Figure 1. Schema representing the developmental trajectories of body fat from intrauterine life to adolescence in healthy girls and boys. Note that although the lines depicting percent body fat in girls and boys were plotted based on reference data from Fomon et al. [23] and Ellis [24], we did not intend to provide values for this body compartment as it can vary depending on the body composition technique used, race/ethnicity, and other factors. Herein, we intended to present an overview of the general expansion patterns of adiposity stratified by sex.

On the other hand, unhealthy expansion is often observed in individuals with obesity under a persistent positive energy balance [11,22]. In these individuals, there is a rapid increase of pre-existing adipocyte size in SAT due to greater lipid accumulation. With inadequate angiogenesis, the tissue is prone to hypoxia and adipocyte dysfunction. Because there is a limit for lipid storage in adipocytes, adipocyte hypertrophy is followed by hyperplasia, or leakage of lipids to other tissues (e.g., liver and muscle), and consequent de novo lipogenesis and lipotoxicity [11,22]. According to Sethi et al., the degree of toxicity will depend on the extent and duration of positive energy supply, effectiveness of lipid transport and storage mechanisms, and organ oxidative capacity [25]. In contrast to this "limited adiposity expandability" hypothesis, a recent study demonstrated that greater turnover of triglycerides and mature adipocytes in abdominal and gluteal SAT of adolescents girls with obesity may determine the accumulation of fat in the liver and metabolic dysfunction in this population [26]. Another hypothesis is that a persistent positive energy balance affects the secretion of adipokines (e.g., leptin, adiponectin, tumor necrosis factor alpha (TNF- $\alpha$ ), interleukin-6 (IL-6)), with implications for glucose homeostasis and lipid metabolism and flux [25]. Further sections will discuss the trajectories of both healthy and unhealthy AT expansion throughout growth stages as well as the evidence regarding factors potentially contributing to AT in each specific life stage (Figure 2). 


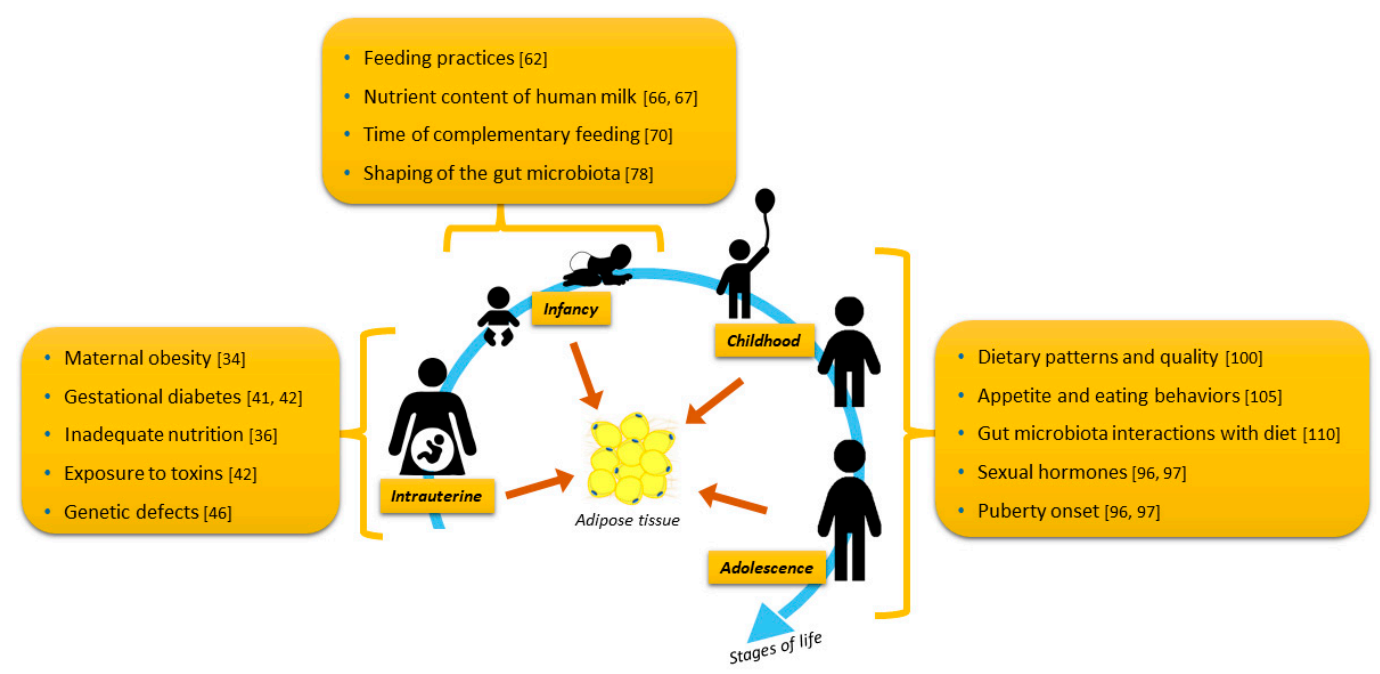

Figure 2. Summary of factors discussed in this review that potentially contribute to adipose tissue development and expansion in the early stages of life.

\subsection{Intrauterine Adipose Tissue Accrual}

Histological analysis of buccal fat pads from human fetuses revealed that intrauterine AT development occurs in five different stages, with an overlap in stages 2 to 4 [27]. The first stage, at 14 weeks, is marked by an outgrowth of loose connective tissue. Right after (stage 2 at 14.5 weeks), there is an early vascularization of the tissue. Stage 3 is characterized by the onset of mesenchymal cell growth at 19 weeks; although several studies have shown a mesodermal origin of these growth cells, recent investigation using mouse models suggests that mesenchymal cells associated with head AT formation originate from neural crest cells [28]. The first adipocytes appear in stage 4, and at 28 weeks (stage 5), fat lobules are formed and can be distinguished from other structures. Despite the later development of adipocytes, findings from molecular body composition analysis estimated a lipid accretion rate of $7.8 \mathrm{~g} /$ day at earlier stages (24-28 weeks) and increases up to $19.8 \mathrm{~g} / \mathrm{day}$ at 36-40 weeks [29]. There is extremely limited knowledge on intrauterine AT accrual in the third trimester of pregnancy due to the inability of current techniques to assess body composition [30]. Using magnetic resonance imaging (MRI), one study reported increases of $2.5 \mathrm{~mm}$ in the truncal AT thickness of fetuses from weeks 29 to $39-40$ of gestational age [31].

\subsubsection{Health and Nutrition during Pregnancy as Determinants of Adipose Tissue}

Prenatal maternal health and nutritional status have been shown to contribute to obesity development during childhood and adolescence [32,33]. Findings from a large study including 1173 mother-child pairs (mostly Caucasians) demonstrated that maternal obesity during early pregnancy was associated with a 0.63 standard deviation increase in body mass index (BMI) $z$-score $(p=0.006)$ and a $11.5 \%$ increase in sum of skinfold thickness $(p<0.001)$ in children at 6 years old (adjusted analysis for maternal covariates) [34]. More specifically, VAT thickness (measured by ultrasound) in the first trimester explained the variations in newborn birth weight centile to the greatest extent compared to SAT and BMI $\left(\mathrm{R}^{2}=15.8 \%, p=0.002\right)$ [35]. Interestingly, maternal diet quality (assessed by the Healthy Eating Index-2015) during pregnancy and lactation was positively associated with infant percent body fat (\%BF) and FM (in kg, by air-displacement plethysmography (ADP)) at 6 months of age [36]. Furthermore, although it is clear that an imbalance between $\omega-6$ and $\omega-3$ polyunsaturated fatty acids intake during pregnancy affects children's neurocognitive development [37], the effects of prenatal $\omega-3$ polyunsaturated fatty acid supplementation on children's obesity risk and AT expansion remain to be confirmed [38].

Increasing maternal blood glucose concentrations have been associated with adverse pregnancy outcomes. The relationships between maternal glucose metabolism (assessed by oral glucose tolerance 
test (OGTT) and glycated hemoglobin) during pregnancy and children's \%BF at 10 to 14 years were evaluated by Lowe Jr. et al. [39]. After adjusting for confounders (e.g., child's sexual maturation, adiposity, and maternal variables), the authors found that the odds ratio (OR) for having high $\% \mathrm{BF}$ ( $>85$ th percentile for age and sex; measured by ADP) during childhood and adolescence ranged from 1.14 to 1.18 for maternal glucose markers, all $p<0.05$ [39]. Other studies also indicated that exposure to gestational diabetes during fetal growth may impact children's adiposity $[40,41]$.

\subsubsection{Effects of Intrauterine Exposure to Toxins on Adipose Tissue Development}

Maternal exposure to toxins and endocrine disrupting chemicals, such as bisphenol A that is found in plastics, has been shown to affect fetal AT development [42]. Bisphenol A appears to cross the placenta, and researchers have quantified human exposure in several body fluids, including breast milk, umbilical cord blood, and amniotic fluid. Although several animal studies confirm prenatal exposure to bisphenol A and its effects on health through the peroxisome proliferator-activated receptors pathways (see Shafei et al., for a detailed description on the mechanism), epidemiological studies have not been conducted to investigate the implication of bisphenol A in adiposity development in humans [43]. The effects of prenatal exposure to smoking and air pollution on infant adiposity and body weight have been Start evaluated in the Healthy study [44,45]. Infants born from mothers who were active smokers or exposed to second-hand smoke during gestation had lower birth weight and FM (by ADP) than non-exposed infants [44]. Furthermore, researchers found positive associations between ozone in the third trimester of pregnancy and infant adiposity at the five-month follow-up, although the average of air pollutants was considered low [45].

\subsubsection{Genetic Defects}

Structural changes in genes including deletions, variations, or mutations in proteins responsible for encoding proteins related to metabolism and appetite regulation can lead to genetic forms of obesity [46]. These genetic variants can be inherited in an autosomal or x-linked pattern, and there are currently three classifications for genetic obesity: monogenic, syndromic, and polygenic obesity [46]. Monogenic non-syndromic obesity results from a single-gene mutation associated with increased appetite (i.e., hyperphagia), early onset severe obesity, and endocrine dysfunction in some patients [47]. Several single-gene mutations have been identified, including dysfunctions in the leptin (LEP) gene and its receptor $(L E P R)$ or regulator $(S H 2 B$ adaptor protein $1(S H 2 B 1))$, proopiomelanocortin $(P O M C)$ gene, and melanocortin 4 receptor $(M C 4 R)$ [47]. Syndromic obesity results from single- or multiple-gene mutations but differs from the other two by the characteristic cognitive delay, dysmorphic features, extreme hyperphagia, organ-specific abnormalities, and other characteristics of hypothalamic dysfunction [48]. More recently, analysis of whole-exome sequencing data from a large cohort of children with severe early onset of obesity revealed variants in the pleckstrin homology domain interacting protein (PHIP) that were associated with obesity, either in the presence or absence of developmental delay [49]. Using in vitro analysis, the authors further demonstrated that variants in the nuclear PHIP suppressed the transcription of the POMC gene, which may contribute to hyperphagia [49]. On the other hand, polygenic obesity is characterized by multiple-gene dysfunction that results in obesity due to their interaction with the environment [50]. Importantly, polygenes enclose one allele that is susceptible to higher and another to lower body weight. More than 100 polygenes associate with body weight regulation have been described as a result of the implementation of genome-wide association studies. It is not our intent to describe the clinical features of these genetic forms of obesity; thus, we refer the readers to the recent reviews cited above.

\subsection{Postnatal and Infant Adipose Tissue Accrual}

Soon after birth, newborns lose body weight due to changes in hydration of fat-free mass (FFM), but not FM [51], as an adaptation to extrauterine life. Fat mass development is marked by steep increases from birth up to 6 months of age and a subsequent reduction in the rate of FM accrual 
in healthy term boys and girls, as assessed by multicompartment model [52]. In fact, \%BF accrual during infancy also differs between term and preterm newborns. Preterm infants at term-corrected age (i.e., chronologic age adjusted for gestational age) had higher $\% B F(14.8 \% \pm 4.4 \%$ by ADP) than term infants $(8.6 \% \pm 3.71 \%, p<0.0001)$ [53]. Similar findings using ADP were reported by Ramel et al. in a longitudinal analysis; preterm infants with appropriate size for gestational age (AGA) at term-corrected age had higher \%BF than term infants $(17.8 \%$ vs. $15.2 \%, p<0.0001)$, but these differences disappeared in measures obtained at 3 to 4 months (27.7\% vs. $23.9 \%, p=0.07)$ [54]. Regarding the distribution of body fat, Toro-Ramos et al. summarized the findings from several studies reporting infant body composition data and highlight the predominance of SAT rather than VAT in the first months of life [30].

Compared to AGA infants, those infants born small for-gestational age (SGA) were shown to have lower \%BF by ADP at term birth [55]. According to Zegher et al., the greater levels of circulating preadipocyte factor 1 (Pref-1) found in SGA than in AGA newborns may partially explain the impaired intrauterine AT development [56], as Pref-1 has a role in suppressing adipocyte differentiation [57]. In contrast, SGA infants experienced subsequent rapid gains in body weight and normalization of $\% B F$ by one year, which has been associated with metabolic disturbances [56]. Catch-up in growth was accompanied by thicker carotid intima-media thickness at 1 and 2 years old, and greater pre-peritoneal fat at 2 years old; however, no differences in cardiovascular markers or cardiac morphometry were found [56]. Furthermore, findings from the Generation R Study revealed that children with a growth pattern characterized by negative fetal weight gain, but consecutive increases in weight during infancy, had the greatest VAT volume (by MRI adjusted for height cubed) and liver fat fraction at a mean age of 9.8 years [58]. In order to further investigate the molecular mechanisms underlying the associations between catch-up growth and metabolic disturbances, animal models may be used; it is noteworthy, however, that researchers should interpret the findings in view of the litter sizes, as smaller ones may have greater access to food leading to overfeeding and higher rates of early growth [59].

\subsubsection{Associations between Feeding Practices and Adipose Tissue in Infancy}

Feeding practices during infancy have been associated with excess adiposity. The benefits of breastfeeding to infant's health have been extensively described in the literature and includes, for example, improved immunity and cognitive development $[60,61]$. However, there is contradictory evidence on whether breastfeeding influences AT development. One study has shown positive associations between exclusive breastfeeding duration and \%BF (by ADP) and SAT (by ultrasound), but not VAT at 3 and 6 months [62]. Comparisons between breastfed and formula-fed healthy newborns from low-risk pregnancies revealed greater \%BF (using ADP) at 3 and 6 months in those who were breastfed [63]. In contrast, no differences in \%BF or FM (also by ADP) were found between predominantly breastfed and exclusively formula-fed infants at 1, 4, and 7 months of age in another study [64]. Some evidence suggests that feeding practices determine the extent of FM accretion and metabolic disturbances in SGA infants early in life [65]. More specifically, breastfed SGA and AGA infants had similar FM levels (by dual-energy X-ray absorptiometry (DXA)) and greater insulin sensitivity at 12 months, whereas SGA infants fed with a protein-rich infant formula experienced gains in FM and decreases in high-molecular-weight (HMW) adiponectin and elevated levels of insulin-like growth factor 1 (IGF-1) [65].

Indeed, the nutrient content of human milk appears to influence AT development as negative associations between carbohydrate content in human milk and FM or \%BF (by ultrasound) have been reported in infants aged 2, 5, 9, and/or 12 months [66]. Differences in human milk fatty acid composition have also been shown to determine adiposity in exclusively breastfed infants [67,68]. For example, \%BF (by ADP) increased $4.7 \%$ in infants (from the ages of two weeks to four months) for each 1-unit increase in the $\omega-6$ to $\omega-3$ polyunsaturated fatty acids ratio $(p=0.010)$ in human milk [67]. Specifically, human milk samples with a high ratio of $\omega-6$ to $\omega-3$ polyunsaturated fatty acids had greater concentrations of pro-inflammatory cytokines (IL-6 and TNF- $\alpha$ ) than samples with medium and low 
ratios, which stimulated the expression of genes responsible for depositing triacylglycerol in adipose cells [68]. Furthermore, associations between hormones in breast milk and infant adiposity measures have also been investigated; higher levels of leptin and intermediate levels of insulin were found to be associated with lower weight-for-length and BMI z-scores at 4 and 12 months of age, independent of several covariates (i.e., maternal pre-pregnancy BMI, ethnicity, parity, diabetes, smoking, breastfeeding exclusivity at sampling, and lactation stage) [69]. Thus, infants may respond differently to breastfeeding regarding AT development because nutrient and hormone content of human milk, which varies among mothers, can affect this association.

The time of complementary feeding introduction is also a determining factor for adiposity accrual early in life and during childhood. A prospective study has shown that children who were breastfed during infancy and had complementary feeding initiated earlier than 4 months had a greater likelihood of presenting with higher truncal fat (by DXA) in mid-childhood ( $\beta=0.33$ [95\% CI, 0.01, 0.65]) and early adolescence $(\beta=1.20$ [95\% CI, 0.33, 2.06]) than breastfed children who had complementary feeding initiated at 4 to 6 months [70]. Similar associations were found in formula-fed children; complementary feeding earlier than 4 months was positively associated with truncal fat at mid-childhood $(\beta=0.52$ $[95 \% \mathrm{CI}, 0.07,0.97])$ and $\% \mathrm{BF}$ at early adolescence $(\beta=2.55[95 \% \mathrm{CI}, 0.20,4.91])$. Interesting, $82 \%$ of the children who received complementary feeding at earlier than 4 months had infant cereals, whereas $30 \%$ had fruits, $22 \%$ were fed vegetables, and 30\% fruit juice [70].

\subsubsection{Gut Microbiome}

The gut microbiome during the first years of life also plays a role in adiposity development and is influenced by several factors, including mode of delivery, feeding practices, antibiotic and drug use, and environmental exposures [71]. The associations between these factors and risk of obesity development have been evaluated in humans [72-74]. For example, a report from the Canadian Healthy Infant Longitudinal Development (CHILD) birth cohort has shown that infants born by caesarean delivery from mothers with overweight were five times more likely to present as overweight by one year old [73]; this association was mediated by the abundance of organisms from the Lachnospiraceae family, which was high in the infant gut microbiome at 3-4 months old. Additionally, a subset of breastfed infants from the same birth cohort had a lower risk of becoming overweight at 12 months than formula-fed infants; authors also found a negative association between breastfeeding exclusiveness and the abundance of Lachnospiraceae organisms [75]. Regarding antibiotic use, a recent meta-analysis found a small association between antibiotic use during infancy and risk of children becoming overweight or obese (based on weight indices) at older age (OR $=1.05 ; 95 \%$ CI 1.00, 1.11), as previous studies have presented controversial results [74]. Despite these findings, mechanistic studies using germ-free animal models have confirmed the causal role of gut microbiome in the obesity pathogenesis and the associations between Lachnospiraceae family and adiposity development [76-79]. Please see Kincaid et al. for a comprehensive review of the literature discussing the most recent animal and human evidence on the interactions between gut microbiome, early life exposures, and obesity onset [78].

\subsection{Adipose Tissue Development in Childhood and Adolescence}

There are a limited number of studies evaluating adiposity between the ages of two and five due to limitations of current body composition techniques, including lack of age-specific predictive equations, minimal movement required for exam success, and lack of appropriate devices for small bodies or that can be used in children across all age stages (e.g., ADP is unavailable for children aged two to six years) $[80,81]$. Using data from reference children, Fomon et al. reported low \%BF accrual rates in early childhood, with boys and girls presenting with $19.5 \%$ and $20.4 \%$ of $\%$ BF at 2 years and $14.6 \%$ and $16.7 \%$ at 5 years, respectively [23]. More recently, Wells et al. reported cross-sectional reference data for adiposity (FM and FM index (FMI)) estimated by isotope dilution from the ages of 6 weeks to 5 years old [82]. However, several studies in populations with varied ethnic origins have reported body composition reference data for late childhood and adolescence, as summarized below. 
Using a longitudinal design, McConnell-Nzunga et al. investigated the \%BF accrual (by DXA) in Canadians of Caucasian and Asian origins from ages 10 to 18 years [83]. The authors found that those children in the highest \%BF centiles (90th and 97th) had greater increases in \%BF from 10 to 11 years, but a sharp reduction from 12 to 15 years. In a study on Caucasian children from Southern England, \%BF peaked at age 11 years for those in the 50th percentile; after this age, \%BF decreased in boys but rose progressively up to 18 years in girls [84]. Comparing \%BF between sexes at age 18, girls had $60 \%$ more $\% \mathrm{BF}$ than boys. A similar pattern of \%BF accrual was observed in a recent study in Southern Brazilians; although a cross-sectional design was used to acquire data, girls in the 50th percentile had higher \%BF with advancing ages. It is interesting to note that the 50th percentile had a flat shape in boys, but the 97th showed a lower FM $(\mathrm{kg})$ from 13 to 16 years, which was again higher with older ages [85]. In summary, although these studies have assessed body composition in children and adolescents of distinct ethnic origins, adiposity accrual appears to follow a similar pattern across ethnicities. With the onset of puberty, adiposity levels decrease in boys along with concurrent FFM increases, while adiposity increases in girls.

Similar to whole-body adiposity accrual, the pattern of adiposity distribution is also sex dependent. For instance, Taylor et al. compared FM in the trunk, waist, and hip lines (measured by DXA) between males and females at different pubertal stages [86]. Sex differences in trunk fat appeared at late puberty (Tanner stages $4-5)$, with boys having $17 \%$ greater trunk fat than girls $(p<0.001)$. Regarding FM at the waistline (i.e., android fat), sexual dimorphisms were observed at all puberty stages (boys having greater fat than girls); on the other hand, girls had greater amount of fat at the hip (i.e., gynoid fat) than boys [86]. Using MRI, a more accurate technique, Shen et al. compared SAT and VAT between sexes; results from regression analysis showed sexual dimorphism in SAT also after entering puberty, with girls having a larger SAT volume than boys [87]. Differences in VAT between sexes were not significant during adolescence but became clearer with advancing age. An ecological explanation for this sexual dimorphism is that with puberty, females need to store energy in SAT for the subsequent period of pregnancy and lactation [88]. We refer the readers to Chang et al. [89] for a recent review on potential factors explaining the sex differences in AT development, expansion, and metabolism.

It is also noteworthy that adolescent pregnancy may affect the patterns of adiposity expansion to support fetal development as well as to prepare the mother for the lactation period [90]. However, there is limited data on maternal body composition during gestation in adolescents or adults due to the changes in uterine contents and total body water that affect the technique's underlying assumptions [90]. In adults, gains in whole-body FM occur throughout pregnancy, as assessed by four-compartment models [91,92], and ADP and quantitative magnetic resonance [93]. Furthermore, pregnant women experience marked increases in thigh and suprailiac skinfolds (which are surrogate measures of subcutaneous AT) during the first six months of gestation but mobilization of these adiposity depots in the last 10-12 weeks of pregnancy to enhance fetal growth [94]. To our knowledge, only one study has compared skinfold thickness between pregnant adolescents and adults across gestation [95]. During the first 28 weeks of gestation, growing adolescents showed small increases in triceps and subscapular skinfolds compared to those adolescents who had already attained peak growth and adults, but no differences between groups were found for skinfold thickness at 28 weeks. Even though this study did not assess lower body adiposity, the authors further showed that growing adolescents continue to deposit adiposity in the trunk and arm after week 28 up to postpartum, whereas mature adolescents and adults experienced decreases in these adiposity depots [95].

\subsubsection{Hormonal Influences on Adipose Tissue Expansion among Boys and Girls}

Hormonal differences between boys and girls also explain the characteristic sexual dimorphism of whole-body adiposity and its distribution patterns at puberty [96]. The levels of estrogen, a hormone responsible for suppressing appetite and increasing energy expenditure, are higher in females [96]. Besides regulating energy metabolism, estrogen also increases sympathetic tone and downregulates androgen receptors expression in SAT, favoring lipid accumulation in this fat depot in females [97]. It is 
noteworthy that girls with obesity enter puberty at younger ages than girls with normal weight [98]. The adipokines leptin and adiponectin may play a role in the inverse association between menarche onset and weight status by modulating the hypothalamic-pituitary-gonadal axis [99]. Briefly, leptin activates the hypothalamus through secretion of the hormone kisspeptin to secrete gonadotropin releasing hormone. This hormone then activates the pituitary gland to produce follicle stimulating hormone and luteinizing hormone, resulting in the secretion of estrogen by the ovaries and, consequently, menarche onset. On the other hand, adiponectin inhibits the secretion of gonadotropin releasing hormone and delays puberty onset [99].

\subsubsection{Dietary Intake and Interactions with Gut Microbiome}

Studies have also investigated the implications of dietary patterns on AT expansion during childhood and adolescence. After following 325 children for four years (age period from 3.8 to 7.8 years old), Wosje et al. observed an association between higher fried-food intake and higher FM (using DXA) after adjusting for several biological and lifestyle covariates [100]. Furthermore, a positive association between glycemic load at 9.6 years old and \%BF (by DXA) at 11.7 years old was reported in children at risk of obesity (parents with obesity) [101]. Prospective studies evaluating the associations between diet quality at baseline and FM (by DXA) at follow-up revealed mixed findings. Lower diet quality indices in mid-childhood (8 to 10 years) [102] were associated with greater FM at follow-up (at 10 to 12 years old, respectively). Contrary to these results, Nguyen et al. reported that positive associations between diet quality and BMI were explained by greater FFM index and not \%BF or FMI [103]. The different approaches used to calculate the diet quality index may partially justify the heterogeneous findings.

Appetite and eating behaviors have been shown to influence the development of childhood obesity, as regulation of food intake contributes to energy homeostasis. According to Boswell et al., appetite is related to physiological (homeostatic) and psycho-social needs (hedonic), and eating behaviors are the actions during eating events [104]. In the absence of physiological energy needs, consumption of palatable food characterizes the hedonic eating and triggers the release of dopamine in the nucleus accumbens, leading to overeating and consequent obesity [105]. Thus, hedonic eating is driven by the reward of food consumption and not by metabolic need. Eating behaviors are influenced by many factors, including mothers' eating behaviors [106], stress [107], attention-deficit/hyperactivity disorder [108], and eating disorders (e.g., binge eating and lack of control over eating) [109].

Expansion of AT can also occur during childhood and adolescence as a result of the interactions between dietary components, gut microbiome, and immune cells [110]. A diet low in fermentable fibers is particularly associated with suboptimal production of short-chain fatty acids by the gut microbiome, limiting the beneficial secretion of anorexigenic hormones, anti-inflammatory cytokines, and mucin on the protective intestinal mucus layer [111-113]. Furthermore, a high-fat diet has been shown to promote metabolic endotoxemia, which can lead to increases in AT, inflammation as well as diabetes [114]. Regarding microbiome composition, children with obesity presented with a lower abundance of the beneficial bacteria Akkermansia muciniphila [115] (known to promote barrier integrity) and enriched Bacteroides eggerthii [116] and Bacteroides fragilis [117] (positively associated with adiposity and inflammation). Moreover, negative associations between adiposity indices and the abundance of $A$. muciniphila have been consistently reported in the pediatric population and in animal studies [118,119]. Indeed, an elegant study by Everard et al. demonstrated that treatment with isolated and viable $A$. muciniphila restored the intestinal mucus layer, reduced inflammation, and decreased the ratio of FM/lean mass in mice with diet-induced obesity; one of the proposed mechanisms was through increases in circulating endocannabinoids [119].

\subsubsection{Physical Activity}

Children with obesity generally report lower moderate-to-vigorous physical activity (MVPA) [120] and greater time spent in sedentary behaviors [121], which have been associated with greater adiposity measures [122]. As several randomized controlled trials (RCTs) investigating the effects of exercise on 
\%BF, FM, or AT in healthy children across weight status have been published to date, pooled analyses of their findings were made possible through meta-analyses [123-125]. For example, García-Hermoso et al. reported an effect of a supervised exercise intervention on reducing body fat in children with either healthy weight or overweight/obese, independent of mode and intensity [123]. It is noteworthy, however, that most of the included studies have combined exercise with additional interventions (i.e., dietary counseling and environmental changes), concealing the direct effect of exercise on adiposity measures. Another recent meta-analysis including RCTs of exercise-only interventions with a duration $\geq 4$ weeks in children with overweight or obesity compared the effects of exercise mode on FM and $\%$ BF [124]. Pooled data analysis revealed that combining aerobic and strength exercises resulted in the greatest reductions of adiposity measures, although aerobic exercise alone also reduced adiposity compared to control arms. Moreover, supervised exercise alone was shown to promote reductions in both VAT and SAT in children with overweight or obesity [125].

Even though the meta-analyses discussed above reported positive effects of exercise on adiposity measures, some studies did not observe changes in this body compartment after exercise interventions [126,127]. For instance, a 12-week high-intensity interval training combined with dietary counseling did not result in changes in FM or \%BF (by DXA) and abdominal VAT and SAT (by MRI) as observed in children with obesity aged 7 to 16 years old [126]. As one of the proposed pathways for lipolysis is through the release of growth hormone, the authors suggested that the reduced growth hormone levels and catecholamine responses to acute exercise can be associated with a disadvantage in reduction of adiposity in children with obesity [126]. Another explanation for the lack of positive exercise effects on adiposity resides in the constrained model of energy expenditure proposed by Pontzer [128]. According to the author, the human body compensates for the increases in energy expenditure through exercise by reducing the energy expended in non-physical-activity metabolic activity; therefore, a negative energy balance that results in adiposity changes is unlikely to occur. More recent studies in the adult population have shown that increases in dietary intake accompanied by exercise initiation is a mechanism often observed that contributes to compensation [129,130]. In adolescents with obesity, energy intake ad libitum was greater at the end of long-term exercise programs ( $\geq 12$ weeks) compared to baseline, with compensation being a characteristic of restrained eaters [131,132]. Additionally, the timing of exercise in relation to meal also appears to influence prospective food consumption in adolescents with obesity; although no significant differences were found in ad libitum total energy intake after 60 or $180 \mathrm{~min}$ from an exercise session (30 min), exercising closer to lunch time (60 $\mathrm{min}$ ) led to a reduction of $170 \mathrm{kcal}$ in energy intake [133].

Studies investigating the effects of school- and community-based programs, with a physical activity component, on childhood obesity prevention have been conducted worldwide. To summarize previous research, a systematic review evaluated adiposity-related outcomes from interventions of different designs and found that most of the school-based programs that were RCTs showed improvements on these outcomes [134]. However, community-based programs have yielded mixed findings [134]. After reporting null results on anthropometric indices of adiposity from a two-school-year, community-based healthy lifestyle program conducted in four Spanish cities (children aged 8-10 years), Gómez et al. discussed the limitations that could have contributed to the findings [135]. According to the authors, the young age of participants, length of follow-up, intervention components, and inability to change the environment and current policies were determinant factors that should be addressed in future investigations [135].

\section{Associations between Adipose Tissue in Childhood and Adulthood}

There is evidence that the amount of adiposity at birth and during the first year of life determines its levels in childhood, albeit only a few studies have investigated longitudinal adiposity changes using body composition methods [14-17]. As an example, Admassu et al. explored the associations between FM (assessed by ADP) at term birth and at 4 years of age in healthy Ethiopians [17]. For every increase of $1 \mathrm{~kg}$ in FM at birth, there was a $1.17 \mathrm{~kg} / \mathrm{m}^{2}$ rise in FMI at 4 years old. In addition, FM accrual 
in the first four months was positively associated with FMI at 4 years $(\beta=0.30 ; 95 \% \mathrm{CI}=0.12,0.47)$, after controlling for several sociodemographic and parental covariates [17]. Regarding the tracking of adiposity from childhood to adulthood, a 20-year longitudinal follow-up study showed that whole-body and trunk FM z-scores (by DXA) early in life (entry age 8-15 years) were predictors of these body compartments by the age of 28 years [136].

Studies examining AT samples obtained from biopsies have been conducted to elucidate adipocyte development and expansion during infancy, childhood, and adulthood [137,138]. In a cross-sectional study, infants showed increases in cell size to an adult level from ages 6 months to one year, with reductions between one and two years [137]. Researchers were able to stratify the analysis by weight categories only after age of two year, and it was noted that cell size was greater in children with obesity compared to that in children without obesity. In children of normal weight, adult levels for adipocyte size were reached at 11 to 13 years old; however, cell size in children with obesity was similar to that of adults at age two. Regarding adipocyte cell number, increases were found throughout childhood and adolescence for children with obesity; but those children of normal weight had differences in cell number only after 10 years old [137]. Longitudinal analysis of AT samples confirms a similar pattern of adiposity accrual in cell size and number across infancy and childhood [137]. Furthermore, Spalding et al. compared results from a study in childhood and adolescence with data obtained in adults (aged 20 years and older) and observed no further increases in the number of adipocytes during adulthood [139]. Differences in adipocyte morphology and metabolism also exist across AT depots [9]. In this context, Tarabra et al. reported that adipocytes from omental AT samples were smaller but had a greater lipolytic activity than abdominal SAT in adolescent girls (16-22 years old) with severe obesity [140].

Although adults with obesity showed a greater amount of AT cells than those of normal weight, the number of cells remained similar to that observed at younger ages [21]. More recently, research using in vivo analysis has shown that adipocyte cells can undergo a process called de novo adipogeneses (i.e., adipocyte turnover) contributing to obesity onset [141]. Once adulthood is reached, there is also a pattern that is specific to weight status with regards to adipocyte turnover (death of adipocytes and generation of new cells). For example, although there seems to be no differences in the death rate of adipocytes across weight status, adults with obesity had 2.6 times the number of adipocytes generated per year than adults with normal weight [139].

These findings, however, should be interpreted with caution due to the technical limitations of AT biopsy and analysis, anatomic sampling location, and interindividual variability [9,142,143]. In fact, Laforest et al. compared the diameter of adipocytes from abdominal SAT of adult women using three distinct techniques (i.e., collagenase digestion, osmium tetroxide fixation, and histological analysis) and found different results between these approaches [143]. Using counting methods, previous studies have estimated the percentage of adipocytes in AT ranging from $\sim 15 \%$ to $\sim 93 \%$, as reviewed by Lenz et al. [9]. Furthermore, it has been suggested that the lipid droplet may not be completely apparent in AT cross-sectional slices, which can limit the findings from counting methods $[9,144]$. Techniques considered of superior accuracy have been used in more recent research [9,142]. For instance, Glastonbury et al. demonstrated, through analysis of RNA-Seq-based gene expression profile, a median percentage of $62 \%$ adipocytes for lower-leg AT samples obtained by surgical incision (Genotype-Tissue Expression project) and $82 \%$ for abdominal AT samples by punch biopsies (Twins UK study) in adults [142]. Another study employed a combination of whole-tissue microarray and RNA-Seq-based gene expression profile to evaluate adipocyte content in different AT depots, and showed that SAT has the greatest proportion of adipocytes $(74 \%)$ followed by omental AT ( 66\%) [9]. To move forward, standardization of biopsy techniques and biobanking of samples of larger cohorts with at least different biologic characteristics (age, sex, ethnicity, and weight status) are necessary.

In individuals with obesity, the expansion of AT also occurs with concomitant accumulation of AT macrophages (specifically, M1 macrophages) and consequent secretion of pro-inflammatory cytokines. To our knowledge, although longitudinal studies have not yet been conducted in humans to 
evaluate whether macrophage infiltration early in life determines adiposity inflammation in adulthood, there is some evidence that the unhealthy AT expansion takes place across the lifespan. For instance, TNF- $\alpha$ expression in macrophages was greater in cord blood samples from neonates born of mothers with obesity than that in those born of mother without obesity [145]. Furthermore, children with obesity had greater number of macrophages infiltrated in AT compared to that of their lean peers $(p<0.001)$; however, macrophage number was not correlated with serum levels of high-sensitivity c-reactive protein (hs-CRP) nor IL-6 and TNF- $\alpha$ (serum levels and AT expression) [138]. Among adolescents with obesity, those with higher proportions of VAT to total abdominal obesity had also greater AT macrophage infiltration and expression of genes related to the inflammasome containing leucine-rich containing family, pyrin domain containing 3 (NLRP3), which are responsible for mediating pro-inflammatory responses [146]. Moreover, the expression of AT macrophages in both SAT and VAT was positively associated with adiposity measures in adults $[147,148]$. It is noteworthy that the macrophage profile appears to be AT depot specific $[9,149,150]$. To our knowledge, only one study compared SAT and omental AT in adolescent girls with severe obesity; although the differences were not statistically significant, omental AT had a smaller infiltration of CD68+ cells than abdominal SAT $(p=0.09)$ [140]. Moreover, a greater infiltration of macrophages (CD8+ and CD4+ T cells) in epicardial and pericardial AT were found in samples from patients with coronary artery disease and congenital heart disease [9]. Given the pro-inflammatory profile of epicardial and pericardial AT, several studies have investigated their roles on chronic diseases, such as diabetes [151] and cardiovascular diseases [152].

Further cues concerning the etiology of obesity and its related metabolic comorbidities are available from studies investigating monozygotic twins discordant for body weight, in which the influences of intrauterine, genetic, biological (i.e., sex, age, and race/ethnicity), and environmental factors can be ruled out $[153,154]$. These studies have shown twin pairs clustering into groups of distinct metabolic profiles, despite the marked differences in whole-body adiposity within the pairs. Specifically, some twin pairs were metabolically healthy, whereas others had only the co-twin with obesity presenting with concurrent metabolic dysfunction (e.g., fatty liver, insulin resistance). Furthermore, biopsies of abdominal SAT revealed a unique metabolic signature in the co-twins with obesity and metabolically unhealthy, characterized by downregulation of mitochondrial oxidative pathways and upregulation of inflammatory pathways [153,154]. Larger adipocyte size was also observed in the co-twin with obesity compared to the leaner co-twin [153] and in those with metabolic dysfunction [154]. Thus, these findings suggest that factors other than genetics and early life programming of AT may determine obesity and related metabolic comorbidities at adulthood, but previous weight-discordant twin studies have not been powered to determine these factors.

\section{Conclusions and Perspectives}

This narrative review discussed the trajectories of AT development from the prenatal period up to adolescence and identified potential factors determining AT expansion (Figures 1 and 2). We identified that studies assessing developmental trajectories of this body compartment in early childhood (especially from ages 2 to 5 years) are extremely limited. Further research is needed to determine body composition techniques that, when used solely, are accurate and capable of depicting changes in adiposity across the lifespan. Indeed, with this gap in research filled, body composition reference data will be available in multiethnic populations with a varied weight status, contributing to a better understanding of the healthy and unhealthy trajectories of adiposity development. Future longitudinal studies should also evaluate the distribution of AT into distinct SAT and VAT depots throughout childhood and adolescence. Despite these limitations, our work supports the argument that the interval between pregnancy to childhood provides a unique window of opportunity for the prevention of obesity and related comorbidities. Once high levels of adiposity are set, the negative effects of adiposity become noticeable. Thus, these preventive strategies should focus on ensuring adequate maternal nutrition and reduced exposure to toxins for a healthy pregnancy as well as targeting feeding/eating practices and behaviors and gut microbiome composition in infancy and childhood. 
Author Contributions: Conceptualization, C.E.O., C.M.P., and A.M.H.; literature search, C.E.O.; writing-original draft preparation, C.E.O.; writing-review and editing, C.E.O., E.C.-R., C.J.F., K.L.M., C.M.P., and A.M.H. All authors have read and agreed to the published version of the manuscript.

Funding: This work has been funded by the generous support of the Stollery Children's Hospital Foundation through the Women and Children's Health Research Institute (RES0040520). C.E.O. is supported by the Alberta Diabetes Institute and is a recipient of the 2018 Alberta SPOR Graduate Studentship in Patient-Oriented Research, which is jointly funded by Alberta Innovates and the Canadian Institutes of Health Research. C.M.P. is supported by a Canadian Institutes of Health Research New Investigator Salary Award, a Campus Alberta Innovates Program, and a Canadian Foundation for Innovation John R. Evans Leaders Fund (Project \# 34115).

Conflicts of Interest: The authors declare no conflict of interest. A.M.H. has received grant funding from Rhythm pharmaceuticals and Levo therapeutics outside of the submitted work. The funders had no role in the design of the study; in the collection, analyses, or interpretation of data; in the writing of the manuscript; or in the decision to publish the results.

\section{References}

1. NCD Risk Factor Collaboration (NCD-RisC). Worldwide trends in body-mass index, underweight, overweight, and obesity from 1975 to 2016: A pooled analysis of 2416 population-based measurement studies in 128.9 million children, adolescents, and adults. Lancet 2017, 390, 2627-2642. [CrossRef]

2. Kumar, S.; Kelly, A.S. Review of childhood obesity: From epidemiology, etiology, and comorbidities to clinical assessment and treatment. Mayo Clin. Proc. 2017, 92, 251-265. [CrossRef] [PubMed]

3. Heinonen, S.; Jokinen, R.; Rissanen, A.; Pietiläinen, K.H. White adipose tissue mitochondrial metabolism in health and in obesity. Obes. Rev. 2019, 21, 1-23. [CrossRef] [PubMed]

4. Min, S.Y.; Desai, A.; Yang, Z.; Sharma, A.; DeSouza, T.; Genga, R.M.; Kucukural, A.; Lifshitz, L.M.; Nielsen, S.; Scheele, C.; et al. Diverse repertoire of human adipocyte subtypes develops from transcriptionally distinct mesenchymal progenitor cells. Proc. Natl. Acad. Sci. USA 2019, 116, 17970-17979. [CrossRef]

5. Virtanen, K.A.; Lidell, M.E.; Orava, J.; Heglind, M.; Westergren, R.; Niemi, T.; Taittonen, M.; Laine, J.; Savisto, N.J.; Enerbäck, S.; et al. Functional brown adipose tissue in healthy adults. N. Engl. J. Med. 2009, 360, 1518-1525. [CrossRef]

6. Kindler, J.M.; Lobene, A.J.; Vogel, K.A.; Martin, B.R.; McCabe, L.D.; Peacock, M.; Warden, S.J.; McCabe, G.P.; Weaver, C.M. Adiposity, insulin resistance, and bone mass in children and adolescents. J. Clin. Endocrinol. Metab. 2018, 104, 892-899. [CrossRef]

7. Lee, S.J.; Arslanian, S.A. Cardiorespiratory fitness and abdominal adiposity in youth. Eur. J. Clin. Nutr. 2007, 61, 561-565. [CrossRef]

8. Schvey, N.A.; Marwitz, S.E.; Mi, S.J.; Galescu, O.A.; Broadney, M.M.; Young-Hyman, D.; Brady, S.M.; Reynolds, J.C.; Tanofsky-Kraff, M.; Yanovski, S.Z.; et al. Weight-based teasing is associated with gain in BMI and fat mass among children and adolescents at-risk for obesity: A longitudinal study. Pediatr. Obes. 2019, 14, 1-14. [CrossRef]

9. Lenz, M.; Arts, I.C.; Peeters, R.L.; de Kok, T.M.; Ertaylan, G. Adipose tissue in health and disease through the lens of its building blocks. Sci. Rep. 2020, 10, 1-4. [CrossRef]

10. Cleal, L.; Aldea, T.; Chau, Y.Y. Fifty shades of white: Understanding heterogeneity in white adipose stem cells. Adipocyte 2017, 6, 205-216. [CrossRef]

11. Haylett, W.L.; Ferris, W.F. Adipocyte-progenitor cell communication that influences adipogenesis. Cell Mol. Life Sci. 2020, 77, 115-128. [CrossRef]

12. Laharrague, P.; Casteilla, L. The emergence of adipocytes. In Adipose Tissue Development: From Animal Models to Clinical Conditions; Levy-Marchal, C., Pénicaud, L., Eds.; Karger Medical and Scientific Publishers: Basel, Switzerland, 2010; Volume 19, pp. 21-30.

13. Hao, G.; Wang, X.; Treiber, F.A.; Harshfield, G.; Kapuku, G.; Su, S. Body mass index trajectories in childhood is predictive of cardiovascular risk: Results from the 23-year longitudinal Georgia Stress and Heart study. Int. J. Obes. 2018, 42, 923-925. [CrossRef] [PubMed]

14. Koontz, M.B.; Gunzler, D.D.; Presley, L.; Catalano, P.M. Longitudinal changes in infant body composition: Association with childhood obesity. Pediatr. Obes. 2014, 9, e141-e144. [CrossRef] [PubMed]

15. Ong, K.K.; Emmett, P.; Northstone, K.; Golding, J.; Rogers, I.; Ness, A.R.; Wells, J.C.; Dunger, D.B. Infancy weight gain predicts childhood body fat and age at menarche in girls. J. Clin. Endocrinol. Metab. 2009, 94, 1527-1532. [CrossRef] [PubMed] 
16. Chomtho, S.; Wells, J.C.; Williams, J.E.; Davies, P.S.; Lucas, A.; Fewtrell, M.S. Infant growth and later body composition: Evidence from the 4-component model. Am. J. Clin. Nutr. 2008, 87, 1776-1784. [CrossRef] [PubMed]

17. Admassu, B.; Ritz, C.; Wells, J.C.; Girma, T.; Andersen, G.S.; Belachew, T.; Owino, V.; Michaelsen, K.F.; Abera, M.; Wibaek, R.; et al. Accretion of fat-free mass rather than fat mass in infancy is positively associated with linear growth in childhood. J. Nutr. 2018, 148, 607-615. [CrossRef] [PubMed]

18. Shen, W.; St-Onge, M.; Wang, Z.; Heymsfield, S. Study of body composition: An overview. In Human Body Composition, 2nd ed.; Heymsfield, S., Lohman, T., Wang, Z., Going, S., Eds.; Human Kinetics: Champaign, IL, USA, 2005; pp. 3-14.

19. Lee, M.J.; Wu, Y.; Fried, S.K. Adipose tissue heterogeneity: Implication of depot differences in adipose tissue for obesity complications. Mol. Aspects Med. 2013, 34, 1-11. [CrossRef]

20. Jung, S.M.; Sanchez-Gurmaches, J.; Guertin, D.A. Brown adipose tissue development and metabolism. In Brown Adipose Tissue; Springer: Cham, Switzerland, 2018; pp. 3-36.

21. Lecoutre, S.; Petrus, P.; Rydén, M.; Breton, C. Transgenerational epigenetic mechanisms in adipose tissue development. Trends Endocrinol. Metab. 2018, 29, 675-685. [CrossRef]

22. Sun, K.; Kusminski, C.M.; Scherer, P.E. Adipose tissue remodeling and obesity. J. Clin. Investig. 2011, 121, 2094-2101. [CrossRef]

23. Fomon, S.J.; Haschke, F.; Ziegler, E.E.; Nelson, S.E. Body composition of reference children from birth to age 10 years. Am. J. Clin. Nutr. 1982, 35, 1169-1175. [CrossRef]

24. Ellis, K.J. Human body composition: In vivo methods. Physiol. Rev. 2000, 80, 649-680. [CrossRef] [PubMed]

25. Sethi, J.K.; Vidal-Puig, A.J. Thematic review series: Adipocyte biology. Adipose tissue function and plasticity orchestrate nutritional adaptation. J. Lipid Res. 2007, 48, 1253-1262. [PubMed]

26. Nouws, J.; Fitch, M.; Mata, M.; Santoro, N.; Galuppo, B.; Kursawe, R.; Narayan, D.; Vash-Margita, A.; Pierpont, B.; Shulman, G.I.; et al. Altered in vivo lipid fluxes and cell dynamics in subcutaneous adipose tissues are associated with the unfavorable pattern of fat distribution in obese adolescent girls. Diabetes 2019, 68, 1168-1177. [CrossRef] [PubMed]

27. Poissonnet, C.M.; Burdi, A.R.; Bookstein, F.L. Growth and development of human adipose tissue during early gestation. Early Hum. Dev. 1983, 8, 1-11. [CrossRef]

28. Billon, N.; Monteiro, M.C.; Dani, C. Developmental origin of adipocytes: New insights into a pending question. Biol. Cell 2008, 100, 563-575. [CrossRef]

29. Ziegler, E.E.; O'donnell, A.M.; Nelson, S.E.; Fomon, S.J. Body composition of the reference fetus. Growth 1976, 40, 329-341.

30. Toro-Ramos, T.; Paley, C.; Pi-Sunyer, F.X.; Gallagher, D. Body composition during fetal development and infancy through the age of 5 years. Eur. J. Clin. Nutr. 2015, 69, 1279-1289. [CrossRef]

31. Berger-Kulemann, V.; Brugger, P.C.; Reisegger, M.; Klein, K.; Hachemian, N.; Koelblinger, C.; Weber, M.; Prayer, D. Quantification of the subcutaneous fat layer with MRI in fetuses of healthy mothers with no underlying metabolic disease vs. fetuses of diabetic and obese mothers. J. Perinat. Med. 2012, 40, 179-184.

32. Kwon, E.J.; Kim, Y.J. What is fetal programming?: A lifetime health is under the control of in utero health. Obs. Gynecol. Sci. 2017, 60, 506-519. [CrossRef]

33. Harding, J.; Johnston, B. Nutrition and fetal growth. Reprod. Fertil. Dev. 1995, 7, 539-547. [CrossRef]

34. Dalrymple, K.V.; Thompson, J.M.; Begum, S.; Godfrey, K.M.; Poston, L.; Seed, P.T.; McCowan, L.M.; Wall, C.; Shelling, A.; North, R.; et al. Relationships of maternal body mass index and plasma biomarkers with childhood body mass index and adiposity at 6 years: The Children of SCOPE study. Pediatr. Obes. 2019, 14, 1-12. [CrossRef] [PubMed]

35. Jarvie, E.M.; Stewart, F.M.; Ramsay, J.E.; Brown, E.A.; Meyer, B.J.; Olivecrona, G.; Griffin, B.A.; Freeman, D.J. Maternal adipose tissue expansion, a missing link in the prediction of birth weight centile. J. Clin. Endocrinol. Metab. 2020, 105, e814-e825. [CrossRef] [PubMed]

36. Tahir, M.J.; Haapala, J.L.; Foster, L.P.; Duncan, K.M.; Teague, A.M.; Kharbanda, E.O.; McGovern, P.M.; Whitaker, K.M.; Rasmussen, K.M.; Fields, D.A.; et al. Higher maternal diet quality during pregnancy and lactation is associated with lower infant weight-for-length, body fat percent, and fat mass in early postnatal life. Nutrients 2019, 11, 632. [CrossRef] [PubMed] 
37. Shrestha, N.; Sleep, S.L.; Cuffe, J.S.; Holland, O.J.; Perkins, A.V.; Yau, S.Y.; McAinch, A.J.; Hryciw, D.H. Role of omega-6 and omega-3 fatty acids in fetal programming. Clin. Exp. Pharmacol. Physiol. 2020, 47, 907-915. [CrossRef]

38. Vahdaninia, M.; Mackenzie, H.; Dean, T.; Helps, S. The effectiveness of $\omega-3$ polyunsaturated fatty acid interventions during pregnancy on obesity measures in the offspring: An up-to-date systematic review and meta-analysis. Eur. J. Nutr. 2019, 58, 2597-2613. [CrossRef]

39. Lowe, W.L., Jr.; Lowe, L.P.; Kuang, A.; Catalano, P.M.; Nodzenski, M.; Talbot, O.; Tam, W.H.; Sacks, D.A.; McCance, D.; Linder, B.; et al. Maternal glucose levels during pregnancy and childhood adiposity in the Hyperglycemia and Adverse Pregnancy Outcome Follow-up Study. Diabetologia 2019, 62, 598-610. [CrossRef]

40. Hockett, C.W.; Harrall, K.K.; Moore, B.F.; Starling, A.P.; Bellatorre, A.; Sauder, K.A.; Perng, W.; Scherzinger, A.; Garg, K.; Ringham, B.M.; et al. Persistent effects of in utero overnutrition on offspring adiposity: The Exploring Perinatal Outcomes among Children (EPOCH) study. Diabetologia 2019, 62, 2017-2024. [CrossRef]

41. Wang, J.; Pan, L.; Liu, E.; Liu, H.; Liu, J.; Wang, S.; Guo, J.; Li, N.; Zhang, C.; Hu, G. Gestational diabetes and offspring's growth from birth to 6 years old. Int. J. Obes. 2019, 43, 663-672. [CrossRef]

42. Hoepner, L.A. Bisphenol A: A narrative review of prenatal exposure effects on adipogenesis and childhood obesity via peroxisome proliferator-activated receptor gamma. Environ. Res. 2019, 173, 54-68. [CrossRef]

43. Shafei, A.E.; Nabih, E.S.; Shehata, K.A.; Abd Elfatah, E.S.; Sanad, A.B.; Marey, M.Y.; Hammouda, A.A.; Mohammed, M.M.; Mostafa, R.; Ali, M.A. Prenatal exposure to endocrine disruptors and reprogramming of adipogenesis: An early-life risk factor for childhood obesity. Child. Obes. 2018, 14, 18-25. [CrossRef]

44. Moore, B.F.; Starling, A.P.; Magzamen, S.; Harrod, C.S.; Allshouse, W.B.; Adgate, J.L.; Ringham, B.M.; Glueck, D.H.; Dabelea, D. Fetal exposure to maternal active and secondhand smoking with offspring early-life growth in the Healthy Start study. Int. J. Obes. 2019, 43, 652-662. [CrossRef] [PubMed]

45. Starling, A.P.; Moore, B.F.; Thomas, D.S.K.; Peel, J.L.; Zhang, W.; Adgate, J.L.; Magzamen, S.; Martenies, S.E.; Allshouse, W.B.; Dabelea, D. Prenatal exposure to traffic and ambient air pollution and infant weight and adiposity: The Healthy Start study. Environ. Res. 2020, 8, 109130. [CrossRef] [PubMed]

46. Pigeyre, M.; Yazdi, F.T.; Kaur, Y.; Meyre, D. Recent progress in genetics, epigenetics and metagenomics unveils the pathophysiology of human obesity. Clin. Sci. 2016, 130, 943-986. [CrossRef] [PubMed]

47. Pigeyere, M.; Meyre, D. Monogenic obesity. In Pediatric Obesity: Etiology, Pathogenesis and Treatment, 2nd ed.; Freemark, M.S., Ed.; Springer International Publishing: New York, NY, USA, 2018; pp. 135-152.

48. Irizarry, K.A.; Haqq, A.M. Syndromic obesity. In Pediatric Obesity: Etiology, Pathogenesis and Treatment, 2nd ed.; Freemark, M.S., Ed.; Springer International Publishing: New York, NY, USA, 2018; pp. 153-182.

49. Marenne, G.; Hendricks, A.E.; Perdikari, A.; Bounds, R.; Payne, F.; Keogh, J.M.; Lelliott, C.J.; Henning, E.; Pathan, S.; Ashford, S.; et al. Exome sequencing identifies genes and gene sets contributing to severe childhood obesity, linking PHIP variants to repressed POMC transcription. Cell Metab. 2020, 31, 1107-1119. [CrossRef]

50. Hinney, A.; Giuranna, J. Polygenic obesity. In Pediatric Obesity: Etiology, Pathogenesis and Treatment, 2nd ed.; Freemark, M.S., Ed.; Springer International Publishing: New York, NY, USA, 2018; pp. 183-204.

51. Moulton, C.R. Age and chemical development in mammals. J. Biol. Chem. 1923, 57, 79-97.

52. Griffin, I.J.; Cooke, R.J. Development of whole body adiposity in preterm infants. Early Hum. Dev. 2012, 88, S19-S24. [CrossRef]

53. Roggero, P.; Giannì, M.L.; Amato, O.; Orsi, A.; Piemontese, P.; Morlacchi, L.; Mosca, F. Is term newborn body composition being achieved postnatally in preterm infants? Early Hum. Dev. 2009, 85, 349-352. [CrossRef]

54. Ramel, S.E.; Gray, H.L.; Ode, K.L.; Younge, N.; Georgieff, M.K.; Demerath, E.W. Body composition changes in preterm infants following hospital discharge: Comparison with term infants. J. Pediatr. Gastroenterol. Nutr. 2011, 53, 333-338. [CrossRef]

55. Sebastiani, G.; García-Beltran, C.; Pie, S.; Guerra, A.; López-Bermejo, A.; de Toledo, J.S.; de Zegher, F.; Rosés, F.; Ibáñez, L. The sequence of prenatal growth restraint and postnatal catch-up growth: Normal heart but thicker intima-media and more pre-peritoneal fat in late infancy. Pediatr. Obes. 2019, 14, e12476. [CrossRef]

56. De Zegher, F.; Díaz, M.; Sebastiani, G.; Martín-Ancel, A.; Sánchez-Infantes, D.; López-Bermejo, A.; Ibáñez, L. Abundance of circulating preadipocyte factor 1 in early life. Diabetes Care 2012, 35, 848-849. [CrossRef]

57. Wang, Y.; Kim, K.A.; Kim, J.H.; Sul, H.S. Pref-1, a preadipocyte secreted factor that inhibits adipogenesis. J. Nutr. 2006, 136, 2953-2956. [CrossRef] [PubMed] 
58. Vogelezang, S.; Santos, S.; Toemen, L.; Oei, E.H.; Felix, J.F.; Jaddoe, V.W. Associations of fetal and infant weight change with general, visceral, and organ adiposity at school age. JAMA Netw. Open 2019, 2, e192843. [CrossRef] [PubMed]

59. Parra-Vargas, M.; Ramon-Krauel, M.; Lerin, C.; Jimenez-Chillaron, J.C. Size does matter: Litter size strongly determines adult metabolism in rodents. Cell Metab. 2020, 32, 334-340. [CrossRef] [PubMed]

60. Victora, C.G.; Bahl, R.; Barros, A.J.; França, G.V.; Horton, S.; Krasevec, J.; Murch, S.; Sankar, M.J.; Walker, N.; Rollins, N.C. The Lancet Breastfeeding Series Group. Breastfeeding in the 21st century: Epidemiology, mechanisms, and lifelong effect. Lancet 2016, 387, 475-490. [CrossRef]

61. Rollins, N.C.; Bhandari, N.; Hajeebhoy, N.; Horton, S.; Lutter, C.K.; Martines, J.C.; Piwoz, E.G.; Richter, L.M.; Victora, C.G. The Lancet Breastfeeding Series Group. Why invest, and what it will take to improve breastfeeding practices? Lancet 2016, 387, 491-504. [CrossRef]

62. Breij, L.M.; Abrahamse-Berkeveld, M.; Acton, D.; Rolfe, E.D.; Ong, K.K.; Hokken-Koelega, A.C. Impact of early infant growth, duration of breastfeeding and maternal factors on total body fat mass and visceral fat at 3 and 6 months of age. Ann. Nutr. Metab. 2017, 71, 203-210. [CrossRef]

63. Rodríguez-Cano, A.M.; Mier-Cabrera, J.; Allegre-Dávalos, A.L.; Muñoz-Manrique, C.; Perichart-Perera, O. Higher fat mass and fat mass accretion during the first six months of life in exclusively breastfed infants. Pediatr. Res. 2020, 87, 588-594. [CrossRef]

64. Bell, K.A.; Wagner, C.L.; Feldman, H.A.; Shypailo, R.J.; Belfort, M.B. Associations of infant feeding with trajectories of body composition and growth. Am. J. Clin. Nutr. 2017, 106, 491-498. [CrossRef]

65. De Zegher, F.; Sebastiani, G.; Diaz, M.; Gómez-Roig, M.D.; López-Bermejo, A.; Ibáñez, L. Breast-feeding vs formula-feeding for infants born small-for-gestational-age: Divergent effects on fat mass and on circulating IGF-I and high-molecular-weight adiponectin in late infancy. J. Clin. Endocrinol. Metab. 2013, 98, 1242-1247. [CrossRef]

66. Gridneva, Z.; Rea, A.; Tie, W.J.; Lai, C.T.; Kugananthan, S.; Ward, L.C.; Murray, K.; Hartmann, P.E.; Geddes, D.T. Carbohydrates in human milk and body composition of term infants during the first 12 months of lactation. Nutrients 2019, 11, 1472. [CrossRef]

67. Rudolph, M.C.; Young, B.E.; Lemas, D.J.; Palmer, C.E.; Hernandez, T.L.; Barbour, L.A.; Friedman, J.E.; Krebs, N.F.; MacLean, P.S. Early infant adipose deposition is positively associated with the n-6 to n-3 fatty acid ratio in human milk independent of maternal BMI. Int. J. Obes. 2017, 41, 510-517. [CrossRef] [PubMed]

68. Vaidya, H.; Cheema, S.K. Breastmilk with a high omega-6 to omega-3 fatty acid ratio induced cellular events similar to insulin resistance and obesity in 3T3-L1 adipocytes. Pediatric. Obes. 2018, 13, 285-291. [CrossRef] [PubMed]

69. Chan, D.; Goruk, S.; Becker, A.B.; Subbarao, P.; Mandhane, P.J.; Turvey, S.E.; Lefebvre, D.; Sears, M.R.; Field, C.J.; Azad, M.B. Adiponectin, leptin and insulin in breast milk: Associations with maternal characteristics and infant body composition in the first year of life. Int. J. Obes. (Lond.) 2018, 42, 36-43. [CrossRef] [PubMed]

70. Gingras, V.; Aris, I.M.; Rifas-Shiman, S.L.; Switkowski, K.M.; Oken, E.; Hivert, M.F. Timing of complementary feeding introduction and adiposity throughout childhood. Pediatrics 2019, 144, e20191320. [CrossRef] [PubMed]

71. Bäckhed, F.; Roswall, J.; Peng, Y.; Feng, Q.; Jia, H.; Kovatcheva-Datchary, P.; Li, Y.; Xia, Y.; Xie, H.; Zhong, H.; et al. Dynamics and stabilization of the human gut microbiome during the first year of life. Cell Host Microbe 2015, 17, 690-703. [CrossRef]

72. Mueller, N.T.; Whyatt, R.; Hoepner, L.; Oberfield, S.; Dominguez-Bello, M.G.; Widen, E.M.; Hassoun, A.; Perera, F.; Rundle, A. Prenatal exposure to antibiotics, cesarean section and risk of childhood obesity. Int. J. Obes. 2015, 39, 665-670. [CrossRef]

73. Tun, H.M.; Bridgman, S.L.; Chari, R.; Field, C.J.; Guttman, D.S.; Becker, A.B.; Mandhane, P.J.; Turvey, S.E.; Subbarao, P.; Sears, M.R.; et al. Roles of birth mode and infant gut microbiota in intergenerational transmission of overweight and obesity from mother to offspring. JAMA Pediatr. 2018, 172, 368-377. [CrossRef]

74. Miller, S.A.; Wu, R.K.S.; Oremus, M. The association between antibiotic use in infancy and childhood overweight or obesity: A systematic review and meta-analysis. Obes. Rev. 2018, 19, 1463-1475. [CrossRef]

75. Forbes, J.D.; Azad, M.B.; Vehling, L.; Tun, H.M.; Konya, T.B.; Guttman, D.S.; Field, C.J.; Lefebvre, D.; Sears, M.R.; Becker, A.B.; et al. Association of exposure to formula in the hospital and subsequent infant feeding practices with gut microbiota and risk of overweight in the first year of life. JAMA Pediatr. 2018, 172, e181161. [CrossRef] 
76. Caesar, R.; Tremaroli, V.; Kovatcheva-Datchary, P.; Cani, P.D.; Bäckhed, F. Crosstalk between gut microbiota and dietary lipids aggravates WAT inflammation through TLR signaling. Cell Metab. 2015, 22, 658-668. [CrossRef]

77. Cho, I.; Yamanishi, S.; Cox, L.; Methe, B.A.; Zavadil, J.; Li, K.; Gao, Z.; Mahana, D.; Raju, K.; Teitler, I.; et al. Antibiotics in early life alter the murine colonic microbiome and adiposity. Nature 2012, 488, 621-626. [CrossRef] [PubMed]

78. Kincaid, H.J.; Nagpal, R.; Yadav, H. Microbiome-immune-metabolic axis in the epidemic of childhood obesity: Evidence and opportunities. Obes. Rev. 2020, 21, e12963. [CrossRef] [PubMed]

79. Soderborg, T.K.; Clark, S.E.; Mulligan, C.E.; Janssen, R.C.; Babcock, L.; Ir, D.; Young, B.; Krebs, N.; Lemas, D.J.; Johnson, L.K.; et al. The gut microbiota in infants of obese mothers increases inflammation and susceptibility to NAFLD. Nat. Commun. 2018, 9, 1-2. [CrossRef]

80. Gallagher, D.; Andres, A.; Fields, D.A.; Evans, W.J.; Kuczmarski, R.; Lowe, W.L., Jr.; Lumeng, J.C.; Oken, E.; Shepherd, J.A.; Sun, S.; et al. Body composition measurements from birth through 5 years: Challenges, gaps, and existing \& emerging technologies-A National Institutes of Health workshop. Obes. Rev. 2020, 21, e13033. [PubMed]

81. Orsso, C.E.; Silva, M.I.; Gonzalez, M.C.; Rubin, D.A.; Heymsfield, S.B.; Prado, C.M.; Haqq, A.M. Assessment of body composition in pediatric overweight and obesity: A systematic review of the reliability and validity of common techniques. Obes. Rev. 2020, 21, e13041. [CrossRef] [PubMed]

82. Wells, J.C.; Davies, P.S.; Fewtrell, M.S.; Cole, T.J. Body composition reference charts for UK infants and children aged 6 weeks to 5 years based on measurement of total body water by isotope dilution. Eur. J. Clin. Nutr. 2020, 74, 141-148. [CrossRef]

83. McConnell-Nzunga, J.; Naylor, P.J.; Macdonald, H.M.; Rhodes, R.E.; Hofer, S.M.; McKay, H.A. Body fat accrual trajectories for a sample of Asian-Canadian and Caucasian-Canadian children and youth: A longitudinal DXA-based study. Pediatr. Obes. 2020, 15, e12570. [CrossRef]

84. McCarthy, H.D.; Cole, T.J.; Fry, T.; Jebb, S.A.; Prentice, A.M. Body fat reference curves for children. Int. J. Obes. 2006, 30, 598-602. [CrossRef]

85. Ripka, W.L.; Orsso, C.E.; Haqq, A.M.; Luz, T.G.; Prado, C.M.; Ulbricht, L. Lean mass reference curves in adolescents using dual-energy x-ray absorptiometry (DXA). PLoS ONE 2020, 15, e0228646. [CrossRef]

86. Taylor, R.W.; Grant, A.M.; Williams, S.M.; Goulding, A. Sex differences in regional body fat distribution from pre- to postpuberty. Obesity 2010, 18, 1410-1416. [CrossRef]

87. Shen, W.; Punyanitya, M.; Silva, A.M.; Chen, J.; Gallagher, D.; Sardinha, L.B.; Allison, D.B.; Heymsfield, S.B. Sexual dimorphism of adipose tissue distribution across the lifespan: A cross-sectional whole-body magnetic resonance imaging study. Nutr. Metab. (Lond.) 2009, 6, 1-9. [CrossRef] [PubMed]

88. Kaplan, H.S.; Lancaster, J.B. An evolutionary and ecological analysis of human fertility, mating patterns, and parental investment. In Offspring: Human Fertility Behavior in Biodemographic Perspective Panel; Wachter, K., Bulatao, R., Eds.; National Academy of Sciences: Washington, DC, USA, 2003; pp. 170-223.

89. Chang, E.; Varghese, M.; Singer, K. Gender and sex differences in adipose tissue. Curr. Diabetes Rep. 2018, 18, 69. [CrossRef]

90. Widen, E.M.; Gallagher, D. Body composition changes in pregnancy: Measurement, predictors and outcomes. Eur. J. Clin. Nutr. 2014, 68, 643-652. [CrossRef] [PubMed]

91. Kopp-Hoolihan, L.E.; Van Loan, M.D.; Wong, W.W.; King, J.C. Fat mass deposition during pregnancy using a four-component model. J. Appl. Physiol. 1999, 87, 196-202. [CrossRef] [PubMed]

92. Lederman, S.A.; Paxton, A.; Heymsfield, S.B.; Wang, J.; Thornton, J.; Pierson, R.N., Jr. Body fat and water changes during pregnancy in women with different body weight and weight gain. Obstet. Gynecol. 1997, 90, 483-488. [CrossRef]

93. Bosaeus, M.; Andersson-Hall, U.; Andersson, L.; Karlsson, T.; Ellegård, L.; Holmäng, A. Body composition during pregnancy: Longitudinal changes and method comparisons. Reprod. Sci. 2020, 28, 1-3. [CrossRef] [PubMed]

94. Lassek, W.D.; Gaulin, S.J. Changes in body fat distribution in relation to parity in American women: A covert form of maternal depletion. Am. J. Phys. Anthropol. 2006, 131, 295-302. [CrossRef]

95. Scholl, T.O.; Hediger, M.L.; Schall, J.I.; Khoo, C.S.; Fischer, R.L. Maternal growth during pregnancy and the competition for nutrients. Am. J. Clin. Nutr. 1994, 60, 183-188. [CrossRef]

96. Palmer, B.F.; Clegg, D.J. The sexual dimorphism of obesity. Mol. Cell Endocrinol. 2015, 15, 113-119. [CrossRef] 
97. Brown, L.; Clegg, D. Central effects of estradiol in the regulation of adiposity. J. Steroid Biochem. Mol. Biol. 2010, 122, 65-73. [CrossRef]

98. Currie, C.; Ahluwalia, N.; Godeau, E.; Gabhainn, S.N.; Due, P.; Currie, D.B. Is obesity at individual and national level associated with lower age at menarche? Evidence from 34 countries in the health behaviour in school-aged children study. J. Adolesc. Health 2012, 50, 621-626. [CrossRef] [PubMed]

99. Nieuwenhuis, D.; Pujol-Gualdo, N.; Arnoldussen, I.A.; Kiliaan, A.J. Adipokines: A gear shift in puberty. Obes. Rev. 2020, 21, e13005. [CrossRef] [PubMed]

100. Wosje, K.S.; Khoury, P.R.; Claytor, R.P.; Copeland, K.A.; Hornung, R.W.; Daniels, S.R.; Kalkwarf, H.J. Dietary patterns associated with fat and bone mass in young children. Am. J. Clin. Nutr. 2010, 92, 294-303. [CrossRef] [PubMed]

101. Suissa, K.; Benedetti, A.; Henderson, M.; Gray-Donald, K.; Paradis, G. Effects of dietary glycemic index and load on children's cardiovascular risk factors. Ann. Epidemiol. 2019, 40, 1-7. [CrossRef] [PubMed]

102. Setayeshgar, S.; Maximova, K.; Ekwaru, J.P.; Gray-Donald, K.; Henderson, M.; Paradis, G.; Tremblay, A.; Veugelers, P. Diet quality as measured by the Diet Quality Index-International is associated with prospective changes in body fat among Canadian children. Public Health Nutr. 2017, 20, 456-463. [CrossRef]

103. Nguyen-Rodriguez, S.T.; Gallo, L.C.; Isasi, C.R.; Buxton, O.M.; Thomas, K.S.; Sotres-Alvarez, D.; Redline, S.; Castañeda, S.F.; Carnethon, M.R.; Daviglus, M.L.; et al. Adiposity, depression symptoms and inflammation in Hispanic/Latino youth: Results from HCHS/SOL youth. Ann. Behav. Med. 2020, 54, 529-534. [CrossRef]

104. Boswell, N.; Byrne, R.; Davies, P.S.W. Aetiology of eating behaviours: A possible mechanism to understand obesity development in early childhood. Neurosci. Biobehav. Rev. 2018, 95, 438-448. [CrossRef]

105. Appelhans, B.M. Neurobehavioral inhibition of reward-driven feeding: Implications for dieting and obesity. Obesity 2009, 17, 640-647. [CrossRef]

106. Campbell, K.J.; Crawford, D.A.; Salmon, J.; Carver, A.; Garnett, S.P.; Baur, L.A. Associations between the home food environment and obesity-promoting eating behaviors in adolescence. Obesity 2007, 15, 719-730. [CrossRef]

107. Hill, D.C.; Moss, R.H.; Sykes-Muskett, B.; Conner, M.; O'Connor, D.B. Stress and eating behaviors in children and adolescents: Systematic review and meta-analysis. Appetite 2018, 123, 14-22. [CrossRef]

108. Fuemmeler, B.F.; Sheng, Y.; Schechter, J.C.; Do, E.; Zucker, N.; Majors, A.; Maguire, R.; Murphy, S.K.; Hoyo, C.; Kollins, S.H. Associations between attention deficit hyperactivity disorder symptoms and eating behaviors in early childhood. Pediatr. Obes. 2020, 15, e12631. [CrossRef] [PubMed]

109. He, J.; Cai, Z.; Fan, X. Prevalence of binge and loss of control eating among children and adolescents with overweight and obesity: An exploratory meta-analysis. Int. J. Eat. Disord. 2017, 50, 91-103. [CrossRef] [PubMed]

110. Nicolucci, A.C.; Hume, M.P.; Martínez, I.; Mayengbam, S.; Walter, J.; Reimer, R.A. Prebiotics reduce body fat and alter intestinal microbiota in children who are overweight or with obesity. Gastroenterology 2017, 153, 711-722. [CrossRef] [PubMed]

111. Chambers, E.S.; Viardot, A.; Psichas, A.; Morrison, D.J.; Murphy, K.G.; Zac-Varghese, S.E.; MacDougall, K.; Preston, T.; Tedford, C.; Finlayson, G.S.; et al. Effects of targeted delivery of propionate to the human colon on appetite regulation, body weight maintenance and adiposity in overweight adults. Gut 2015, 64, 1744-1754. [CrossRef] [PubMed]

112. Larraufie, P.; Martin-Gallausiaux, C.; Lapaque, N.; Dore, J.; Gribble, F.M.; Reimann, F.; Blottiere, H.M. SCFAs strongly stimulate PYY production in human enteroendocrine cells. Sci. Rep. 2018, 8, 74. [CrossRef]

113. Willemsen, L.E.; Koetsier, M.A.; Van Deventer, S.J.; Van Tol, E.A. Short chain fatty acids stimulate epithelial mucin 2 expression through differential effects on prostaglandin $\mathrm{E}(1)$ and $\mathrm{E}(2)$ production by intestinal myofibroblasts. Gut 2003, 52, 1442-1447. [CrossRef]

114. Cani, P.D.; Amar, J.; Iglesias, M.A.; Poggi, M.; Knauf, C.; Bastelica, D.; Neyrinck, A.M.; Fava, F.; Tuohy, K.M.; Chabo, C.; et al. Metabolic endotoxemia initiates obesity and insulin resistance. Diabetes 2007, 56, 1232-1242. [CrossRef]

115. Borgo, F.; Verduci, E.; Riva, A.; Lassandro, C.; Riva, E.; Morace, G.; Borghi, E. Relative abundance in bacterial and fungal gut microbes in obese children: A case control study. Child. Obes. 2017, 13, 78-84. [CrossRef] 
116. López-Contreras, B.E.; Morán-Ramos, S.; Villarruel-Vázquez, R.; Macías-Kauffer, L.; Villamil-Ramírez, H.; León-Mimila, P.; Vega-Badillo, J.; Sánchez-Muñoz, F.; Llanos-Moreno, L.E.; Canizalez-Román, A.; et al. Composition of gut microbiota in obese and normal-weight Mexican school-age children and its association with metabolic traits. Pediatr. Obes. 2018, 13, 381-388. [CrossRef]

117. Indiani, C.M.; Rizzardi, K.F.; Castelo, P.M.; Ferraz, L.F.; Darrieux, M.; Parisotto, T.M. Childhood obesity and Firmicutes/Bacteroidetes ratio in the gut microbiota: A systematic review. Child. Obes. 2018, 14, 501-509. [CrossRef]

118. Mbakwa, C.A.; Hermes, G.D.; Penders, J.; Savelkoul, P.H.; Thijs, C.; Dagnelie, P.C.; Mommers, M.; Zoetendal, E.G.; Smidt, H.; Arts, I.C. Gut microbiota and body weight in school-aged children: The KOALA birth cohort study. Obesity 2018, 26, 1767-1776. [CrossRef] [PubMed]

119. Everard, A.; Belzer, C.; Geurts, L.; Ouwerkerk, J.P.; Druart, C.; Bindels, L.B.; Guiot, Y.; Derrien, M.; Muccioli, G.G.; Delzenne, N.M.; et al. Cross-talk between Akkermansia muciniphila and intestinal epithelium controls diet-induced obesity. Proc. Natl. Acad. Sci. USA 2013, 110, 9066-9071. [CrossRef] [PubMed]

120. Adamo, K.B.; Colley, R.C.; Hadjiyannakis, S.; Goldfield, G.S. Physical activity and sedentary behavior in obese youth. J. Pediatr. 2015, 166, 1270-1275. [CrossRef]

121. Herman, K.M.; Sabiston, C.M.; Mathieu, M.E.; Tremblay, A.; Paradis, G. Sedentary behavior in a cohort of 8to 10-year-old children at elevated risk of obesity. Prev. Med. (Baltim) 2014, 60, 115-120. [CrossRef] [PubMed]

122. Wiersma, R.; Haverkamp, B.F.; van Beek, J.H.; Riemersma, A.M.; Boezen, H.M.; Smidt, N.; Corpeleijn, E.; Hartman, E. Unravelling the association between accelerometer-derived physical activity and adiposity among preschool children: A systematic review and meta-analyses. Obes. Rev. 2020, 21, e12936. [CrossRef] [PubMed]

123. García-Hermoso, A.; Alonso-Martinez, A.M.; Ramírez-Vélez, R.; Izquierdo, M. Effects of exercise intervention on health-related physical fitness and blood pressure in preschool children: A systematic review and meta-analysis of randomized controlled trials. Sports Med. 2020, 50, 187-203. [CrossRef]

124. Kelley, G.A.; Kelley, K.S.; Pate, R.R. Exercise and adiposity in overweight and obese children and adolescents: A systematic review with network meta-analysis of randomised trials. BMJ Open 2019, 9. [CrossRef]

125. González-Ruiz, K.; Ramirez-Velez, R.; Correa-Bautista, J.E.; Peterson, M.D.; García-Hermoso, A. The effects of exercise on abdominal fat and liver enzymes in pediatric obesity: A systematic review and meta-analysis. Child Obes. 2017, 13, 272-282. [CrossRef]

126. Dias, K.A.; Ingul, C.B.; Tjønna, A.E.; Keating, S.E.; Gomersall, S.R.; Follestad, T.; Hosseini, M.S.; Hollekim-Strand, S.M.; Ro, T.B.; Haram, M.; et al. Effect of high-intensity interval training on fitness, fat mass and cardiometabolic biomarkers in children with obesity: A randomised controlled trial. Sport Med. 2018, 48, 733-746. [CrossRef]

127. Hay, J.; Wittmeier, K.; MacIntosh, A.; Wicklow, B.; Duhamel, T.; Sellers, E.; Dean, H.; Ready, E.; Berard, L.; Kriellaars, D.; et al. Physical activity intensity and type 2 diabetes risk in overweight youth: A randomized trial. Int. J. Obes. (Lond.) 2016, 40, 607-614. [CrossRef]

128. Pontzer, H. Constrained total energy expenditure and the evolutionary biology of energy balance. Exerc. Sport Sci. Rev. 2015, 43, 110-116. [CrossRef] [PubMed]

129. Martin, C.K.; Johnson, W.D.; Myers, C.A.; Apolzan, J.W.; Earnest, C.P.; Thomas, D.M.; Rood, J.C.; Johannsen, N.M.; Tudor-Locke, C.; Harris, M.; et al. Effect of different doses of supervised exercise on food intake, metabolism, and non-exercise physical activity: The E-MECHANIC randomized controlled trial. Am. J. Clin. Nutr. 2019, 110, 583-592. [CrossRef] [PubMed]

130. Riou, M.È.; Jomphe-Tremblay, S.; Lamothe, G.; Finlayson, G.S.; Blundell, J.E.; Décarie-Spain, L.; Gagnon, J.C.; Doucet, É. Energy compensation following a supervised exercise intervention in women living with overweight/obesity is accompanied by an early and sustained decrease in non-structured physical activity. Front. Physiol. 2019, 10, 1-12. [CrossRef] [PubMed]

131. Thivel, D.; Julian, V.; Miguet, M.; Pereira, B.; Beaulieu, K.; Finlayson, G.; Richard, R.; Duclos, M. Introducing eccentric cycling during a multidisciplinary weight loss intervention might prevent adolescents with obesity from increasing their food intake: The TEXTOO study. Physiol. Behav. 2020, 214, 112744. [CrossRef] [PubMed]

132. Miguet, M.; Fearnbach, N.S.; Metz, L.; Khammassi, M.; Julian, V.; Cardenoux, C.; Pereira, B.; Boirie, Y.; Duclos, M.; Thivel, D. Effect of HIIT versus MICT on body composition and energy intake in dietary restrained and unrestrained adolescents with obesity. Appl. Physiol. Nutr. Metab. 2020, 45, 437-445. [CrossRef] 
133. Fillon, A.; Mathieu, M.E.; Masurier, J.; Roche, J.; Miguet, M.; Khammassi, M.; Finlayson, G.; Beaulieu, K.; Pereira, B.; Duclos, M.; et al. Effect of exercise-meal timing on energy intake, appetite and food reward in adolescents with obesity: The TIMEX study. Appetite 2020, 146, 104506. [CrossRef]

134. Bleich, S.N.; Vercammen, K.A.; Zatz, L.Y.; Frelier, J.M.; Ebbeling, C.B.; Peeters, A. Interventions to prevent global childhood overweight and obesity: A systematic review. Lancet Diabetes Endocrinol. 2018, 6, 332-346. [CrossRef]

135. Gómez, S.F.; Esteve, R.C.; Subirana, I.; Serra-Majem, L.; Torrent, M.F.; Homs, C.; Bawaked, R.A.; Estrada, L.; Fíto, M.; Schröder, H. Effect of a community-based childhood obesity intervention program on changes in anthropometric variables, incidence of obesity, and lifestyle choices in Spanish children aged 8 to 10 years. Eur. J. Pediatr. 2018, 177, 1531-1539. [CrossRef]

136. Barbour-Tuck, E.; Erlandson, M.; Muhajarine, N.; Foulds, H.; Baxter-Jones, A. Influence of childhood and adolescent fat development on fat mass accrual during emerging adulthood: A 20-year longitudinal study. Obesity 2018, 26, 613-620. [CrossRef]

137. Knittle, J.L.; Timmers, K.; Ginsberg-Fellner, F.; Brown, R.E.; Katz, D.P. The growth of adipose tissue in children and adolescents: Cross-sectional and longitudinal studies of adipose cell number and size. J. Clin. Investig. 1979, 63, 239-246. [CrossRef]

138. Landgraf, K.; Rockstroh, D.; Wagner, I.V.; Weise, S.; Tauscher, R.; Schwartze, J.T.; Löffler, D.; Bühligen, U.; Wojan, M.; Till, H.; et al. Evidence of early alterations in adipose tissue biology and function and its association with obesity-related inflammation and insulin resistance in children. Diabetes 2015, 64, 1249-1261. [CrossRef]

139. Spalding, K.L.; Arner, E.; Westermark, P.O.; Bernard, S.; Buchholz, B.A.; Bergmann, O.; Blomqvist, L.; Hoffstedt, J.; Näslund, E.; Britton, T.; et al. Dynamics of fat cell turnover in humans. Nature 2008, 453, 783-787. [CrossRef] [PubMed]

140. Tarabra, E.; Nouws, J.; Vash-Margita, A.; Nadzam, G.S.; Goldberg, R.; Van Name, M.; Pierpont, B.; Knight, J.R.; Shulman, G.I.; Caprio, S. The omentum of obese girls harbors small adipocytes and browning transcripts. JCI Insight 2020, 5, e135448. [CrossRef] [PubMed]

141. Jeffery, E.; Church, C.D.; Holtrup, B.; Colman, L.; Rodeheffer, M.S. Rapid depot-specific activation of adipocyte precursor cells at the onset of obesity. Nat. Cell Biol. 2015, 17, 376-385. [CrossRef] [PubMed]

142. Glastonbury, C.A.; Alves, A.C.; Moustafa, J.S.; Small, K.S. Cell-type heterogeneity in adipose tissue is associated with complex traits and reveals disease-relevant cell-specific eQTLs. Am. J. Hum. Genet. 2019, 104, 1013-1024. [CrossRef]

143. Laforest, S.; Michaud, A.; Paris, G.; Pelletier, M.; Vidal, H.; Géloën, A.; Tchernof, A. Comparative analysis of three human adipocyte size measurement methods and their relevance for cardiometabolic risk. Obesity 2017, 25, 122-131. [CrossRef]

144. Lenz, M.; Roumans, N.J.; Vink, R.G.; van Baak, M.A.; Mariman, E.C.; Arts, I.C.; de Kok, T.M.; Ertaylan, G. Estimating real cell size distribution from cross-section microscopy imaging. Bioinformatics 2016, 32, i396-i404. [CrossRef]

145. Cifuentes-Zúñiga, F.; Arroyo-Jousse, V.; Soto-Carrasco, G.; Casanello, P.; Uauy, R.; Krause, B.J.; Castro-Rodríguez, J.A. IL-10 expression in macrophages from neonates born from obese mothers is suppressed by IL-4 and LPS/INF $\gamma$. J. Cell Physiol. 2017, 232, 3693-3701. [CrossRef]

146. Kursawe, R.; Dixit, V.D.; Scherer, P.E.; Santoro, N.; Narayan, D.; Gordillo, R.; Giannini, C.; Lopez, X.; Pierpont, B.; Nouws, J.; et al. A role of the inflammasome in the low storage capacity of the abdominal subcutaneous adipose tissue in obese adolescents. Diabetes 2016, 65, 610-618. [CrossRef]

147. Michaud, A.; Drolet, R.; Noël, S.; Paris, G.; Tchernof, A. Visceral fat accumulation is an indicator of adipose tissue macrophage infiltration in women. Metabolism 2012, 61, 689-698. [CrossRef]

148. Klimcakova, E.; Roussel, B.; Kovacova, Z.; Kovacikova, M.; Siklova-Vitkova, M.; Combes, M.; Hejnova, J.; Decaunes, P.; Maoret, J.J.; Vedral, T.; et al. Macrophage gene expression is related to obesity and the metabolic syndrome in human subcutaneous fat as well as in visceral fat. Diabetologia 2011, 54, 876-887. [CrossRef] [PubMed]

149. Hardy, O.T.; Perugini, R.A.; Nicoloro, S.M.; Gallagher-Dorval, K.; Puri, V.; Straubhaar, J.; Czech, M.P. Body mass index-independent inflammation in omental adipose tissue associated with insulin resistance in morbid obesity. Surg. Obes. Relat. Dis. 2011, 7, 60-67. [CrossRef] [PubMed] 
150. Girón-Ulloa, A.; González-Domínguez, E.; Klimek, R.S.; Patiño-Martínez, E.; Vargas-Ayala, G.; Segovia-Gamboa, N.C.; Campos-Peña, V.; Rodríguez-Arellano, M.E.; Meraz-Ríos, M.A.; Campos-Campos, S.F.; et al. Specific macrophage subsets accumulate in human subcutaneous and omental fat depots during obesity. Immunol. Cell Biol. 2020. [CrossRef] [PubMed]

151. Christensen, R.H.; von Scholten, B.J.; Lehrskov, L.L.; Rossing, P.; Jørgensen, P.G. Epicardial adipose tissue: An emerging biomarker of cardiovascular complications in type 2 diabetes? Ther. Adv. Endocrinol. Metab. 2020, 11, 1-16. [CrossRef]

152. Villasante Fricke, A.C.; Iacobellis, G. Epicardial adipose tissue: Clinical biomarker of cardio-metabolic risk. Int. J. Mol. Sci. 2019, 20, 5989. [CrossRef]

153. Naukkarinen, J.; Heinonen, S.; Hakkarainen, A.; Lundbom, J.; Vuolteenaho, K.; Saarinen, L.; Hautaniemi, S.; Rodriguez, A.; Frühbeck, G.; Pajunen, P.; et al. Characterising metabolically healthy obesity in weight-discordant monozygotic twins. Diabetologia 2014, 57, 167-176. [CrossRef]

154. Muniandy, M.; Heinonen, S.; Yki-Järvinen, H.; Hakkarainen, A.; Lundbom, J.; Lundbom, N.; Kaprio, J.; Rissanen, A.; Ollikainen, M.; Pietiläinen, K.H. Gene expression profile of subcutaneous adipose tissue in BMI-discordant monozygotic twin pairs unravels molecular and clinical changes associated with sub-types of obesity. Int. J. Obes. (Lond.) 2017, 41, 1176-1184. [CrossRef]

(C) 2020 by the authors. Licensee MDPI, Basel, Switzerland. This article is an open access article distributed under the terms and conditions of the Creative Commons Attribution (CC BY) license (http://creativecommons.org/licenses/by/4.0/). 